\title{
Pemanfaatan Limbah Gelas dan Botol Plastik Sebagai Media Tanam Penunjang Peningkatan Pendapatan Masyarakat Melalui Pembentukan Kampung Hidroponik di Lahan Rawa
}

\author{
Sukron Romadhona ${ }^{1}, J_{0 k}$ Sudibya ${ }^{2}$ T. Sutikto ${ }^{3}$,Laily Mutmainnah ${ }^{4}$ Arizona \\ $\mathrm{Rambi}^{5}$ \\ Ilmu Tanah, Fakultas Pertanian Universitas Jember, Jember, Indonesia \\ sukronromadhona.faperta@unej.ac.id
}

\begin{abstract}
Abstrak
Terdapat berbagai macam potensi ide-ide yang kreatif untuk menjalankan usaha dan kegiatan kewirausahaan namun belum banyak yang tergali secara optimal. Di kalangan masyarakat pedesaan yang ada di Kabupaten Jember khususnya Desa Gumukmas Kecamatan Gumukmas yang menjadi salah satu desa penempatan KKN dengan fokus pada desa wisata dan wirausaha sejahtera dengan obyek pengembangan melalui Hidroponik, pembinanan dan kegiatannya diarahkan menuju kegiatan positif yang bersifat entrepreneurship utamanya melalui karang taruna dan ibu rumah tangga. Jenisjenis pembinaan dan kegiatan-kegiatan tersebut mengarahkan para generasi muda untuk mengisi waktu luang di sela-sela kegiatan sekolah untuk mempelajari konsep dan teori sains tanah di beberapa aspek. Penumbuhan jiwa kewirausahaan akan mampu memfasilitasi dan menjembatani konsep teori kewirausahaan dan konsep kemandirian khususnya dari sisi pertanian yang potensial yang menjadi aksi nyata dalam implementasi konsep usaha/bisnis ke praktik bisnis dengan menginternalisasikan nilainilai kemandirian dan semangat berwirausaha pada generasi muda melalui bercocok tanam, lebih jauh lagi kegiatan tersebut dapat merangsang geliat masyarakat untuk mengembangkan desa wisata berbasis "Kampung Hidroponik"Kegiatan wirausaha di bidang pertanian ini, salah satu faktor yang perlu diperhatikan adalah lahan yang digunakan untuk kegiatan budidaya. lahan yang ada saat ini semakin sempit akibat dari lahan-lahan yang di gunakan untuk kegiatan budidaya di alih fungsikan ke bidang lain seperti industri, perumahan, dan lain-lain meningat lokasi pengabdian yaitu Kecamatan Arjasa merupakan salah satu kecamatan yang berkembang pesat. Oleh sebab itu, kegiatan pertanian berbasis lahan sempit harus mampu mengelolah lahan terbatas untuk mendapatkan hasil yang semaksimal mungkin dengan teknik hidroponik. Berdasarkan uraian analisis situasi tersebut, perlu diadakan pelatihan hidroponik bagi masyarakat khususnya genarasi muda yang terhimpun dalam Karang Taruna dan Ibu rumah tangga, yang menjadi obyek pengembangan untuk menggali potensi yang ada. Dengan diadakannya pelatihan Hidroponik diharapkan mampu memunculkan usaha baru yang bernilai positif dikalangan generasi muda.
\end{abstract}

Kata Kunci : Hidroponik; Agribisnis; Lahan Rawa

\section{Abstract}

There are various kinds of creative potential ideas for running a business and entrepreneurial activities have not been explored optimally. Among the village communities in Jember District specifically Gumukmas Village, Gumukmas Sub-district, which is one of the villages where KKN is located focuses on tourism villages and 
prosperous entrepreneurs with object development through Hydroponics, improvement and activities related to activities that function well such as entrepreneurship through youth organizations and housewife. These types of coaching and activities gather young people to fill their spare time between school activities to facilitate land science concepts and theories in several aspects. The growth of the spirit of entrepreneurship will be able to facilitate and bridge the concepts of entrepreneurial theory and the concept of special independence from the agricultural side that has the potential to become a real challenge in the context of small businesses. far more than this activity that can be developed stretching the community to develop a tourism village based on "Kampung Hidroponik" Entrepreneurial activities in this field of agriculture, one of the factors to consider is the land used for cultivation. The existing land is increasingly limited from the land used for aquaculture activities that function as industry, housing, and others remember the location of service, namely Arjasa District, which is one of the fastest growing subdistricts. Therefore, land-based agricultural activities must be able to process limited land to get the maximum possible results from hydroponic techniques.Based on the description of the analysis, it is necessary to have hydroponic training for a special community of young genarations gathered in the Youth and Housewives, which are the object of development to explore the potential that exists. With the holding of training, Hydroponics is expected to bring new positive business among the younger generation.

Keywords: Hydroponics; Agribusiness, Swamp Land

\section{PENDAHULUAN}

Pengembangan potensi setiap desa menjadi salah satu cara untuk mewujudkan kesejahteraan masyarakat dalam suatu desa. Pengembangan potensi desa yang baik dapat dilakukan dengan mendorong etos kerja masyarakat desa dalam partisipasi membangun serta mengembangkan potensi yang dimiliki. Pengembangan potensi desa secara mandiri dapat menyejahterakan masyarakat, meningkatkan perekonomian, dan untuk mengembangkan desa sehingga dapat mengatasi permasalahan kesenjangan dalam pembangunan nasional.

Desa Gumukmas Kecamatan Gumukmas, Kabupaten Jember merupakan salah satu wilayah desa yang ada di wilayah administrasi Kabupaten Jember yang penting untuk dikembangkan dikarenakan sumber daya di wilayah ini relatif tidak ada sama sekali. Di desa ini terdapat sekitar 300 KK, namun dari segi perekonomiannya masih dibilang relatif terbelakang. Di desa tersebut sangat sedikit sekali ditemukan potensi-potensi sumber daya alam (SDA) dan industri yang dapat dikembangkan sehingga menjadi tantangan untuk dilakukan pengembangan di wilayah tersebut, sehingga lebih memajukan masyarakat yang ada disana. Tetapi masih ada potensi yang dapat dikembangkan, yaitu dengan memanfaatkan pekarangan masyarakat yang ada di sana. Pemanfaatan pekarangan rumah di tiap-tiap rumah, masih belum banyak dilakukan dengan baik oleh masyarakat di sana. Pekarangan dibiarkan menganggur dan tidak berproduksi. Padahal, apabila pekarangan tersebut dikelola dengan sungguhsungguh seperti dijadikan tempat budidaya tanaman, tentu saja akan berpotensi 
besar bagi kehidupan masyarakat di Desa Gumukmas tersebut, kendala yang muncul di lokasi pengabdian adalah sebagian besar lahan adalah rawa gambut yang sangat sedikit di maksimalkan untuk pertanian.

Pemanfaatan lahan pekarangan yang dapat dilakukan adalah dengan mengembangkan budidaya tanaman secara vertikultur. Vertikultur menjadi inovasi teknologi budidaya yang cukup baik untuk dikembangkan di pekarangan masyarakat desa tersebut. Vertikultur dapat menjadi alternatif pertanian berkelanjutan. Kelebihan sistem pertanian vertikultur diantaranya yaitu efisiensi penggunaan lahan karena yang ditanam jumlahnya lebih banyak dibandingkan sistem konvensional, penghematan pemakaian pupuk dan pestisida karena pengendalian gulma relatif kecil, mudah dipindahkan, dan juga monitoring/pemeliharaan tanaman relatif mudah. Banyak manfaat yang didapat dengan mengembangkan budidaya secara vertikultur. Vertikultur memang efektif untuk dibudidayakan tanaman hortikultura, karena relatif tanaman hortiultura memiliki waktu panen singkat dan juga berprospek baik untuk dikonsumsi atau dipasarkan dan dapat menjadi tujuan desa wisata kampung hidroponik.

\section{METODE}

Perbaikan kondisi ekonomi masyarakat dapat dilakukan dengan mengurangi secara sedikit demi sedikit kebutuhan warga setiap harinya yaitu meringankan kebutuhan pangan. Kebutuhan pangan yang dapat dicukupi setiap harinya dengan tanaman hortikultura yang ditanam secara subsisten dapat sedikit meringankan beban keluarga dalam mencukupi kebutuhan pangan. Manfaat pemenuhan kebutuhan pangan harian ini akan lebih terasa jika setiap kepala rumah tangga menerpakan program yang ada, sehingga dalam satu kawasan dusun dapat memproduksi beranekaragam produk hortikultura dengan baik. Produktivitas yang tinggi akan memperbaiki perekonomian dusun dengan lebih baik apalagi jika pada dusun tersebut dibuka pasar sederhana degan pangsa pasar dusun-dusun sekitarnya. Kondisi yang ideal untuk perbaikan ekonomi tersebut diperlukan transformasi dengan melibatkan seluruh elemen terkait. Tahapan awal yang perlu dilakukan adalah memahami tipologi masyarakat, gaya hidup dalam pemenuhan kebutuhan pangan serta cara masyarakat dalam melakukan kegiatan pasar. Ketiga inti analisis kebutuhan tersebut kemudian dirincikan mengenai masing- msing kelebihan dan kekurangan yang dimiliki dalam melakukan penilaian.

Pendekatan masyarakat dilakukan dengan berbagai tahap agar nantinya program ini benar-benar dapat dipahami oleh masyarakat sehingga secara mandiri masyarakat benar-benar bisa memanfaatkan potensi untuk pengembangan Desa Gumukmas. Proses yang pertama dilakukan adalah dengan 
sosialisasi dan pelatihan budidaya tanaman hortikultura secara vertikultur,tahapan ini didatangkan para ahli dan peneliti termasuk mahasiswa untuk turut membagi informasi dan pengatahuanh seputar kegiatan budidaya ini. Tahapan selanjutnya adalah Pelatihan MOM (Manajemen Organisasi Masyarakat), layaknya sebuah budidaya pertanian maka juga harus dibentuk kelompok tani sebagai salah satu bentuk sarana tukar informasi perkembangan usaha budidaya dan sebagai kontoler pengembangan usaha budidaya sehingga dibutuhkan pelatihan manejemen organisasi masyarakat yang baik agar nantinya apabila usaha budidaya berkembang pesat serta menjadi sumber ekonomi rakyat akan tercipta lingkungan ekonomi yang kondusif untuk dikembangkan.

\section{HASIL}

Desa Gumukmas Kecamatan Gumukmas, Kabupaten Jember merupakan salah satu desa tergolong desa yang termasuk minim potensi sumber daya. Desa ini juga tergolong desa yang perokonomian relatif terbelakang. Industri-industri di desa ini juga jarang ditemukan. Disini hanya ditemukan industri skala rumah tangga, dan itu tidak universal (tenaga kerja tidak mengambil dari masyarakat, hanya dari kalangan keluarga saja). Hal yang dapat dimanfaatkan di desa ini hanyalah pekarangan penduduk, dimana pekarangan penduduk kurang dimanfaatkan dengan cukup baik. Pekarangan yang kurang dimanfaatkan tersebut perlu dimanfaatkan dengan budidaya secara vertikultur. Oleh karena itu, dengan adanya pelatihan serta praktik budidaya secara vertikultur dengan memanfaatkan pekarangan yang dimiliki masyarakat di Desa Gumukmas, Kecamatan Gumukmas, Kabupaten Jember diharapkan akan dapat meningkatkan perekonomian masyarakat.

Hasil kunjungan lapang juga menunjukkan rata-rata SDM yang ada di Desa Gumukmas masi tergolong menengah kebawah sehingga masyarakat cenderung pasif. Profesi dominan yang dilakukan masyarakat desa adalah sebagai buruh tani. Kondisi latar belakang pendidikan yang rendah pada masyarakat desa juga di iringi oleh banyak msyarakat yang buta huruf sehingga terjadi keterbatasan dalam menerima hal-hal baru dalam bentuk pengembangan inovasi. 


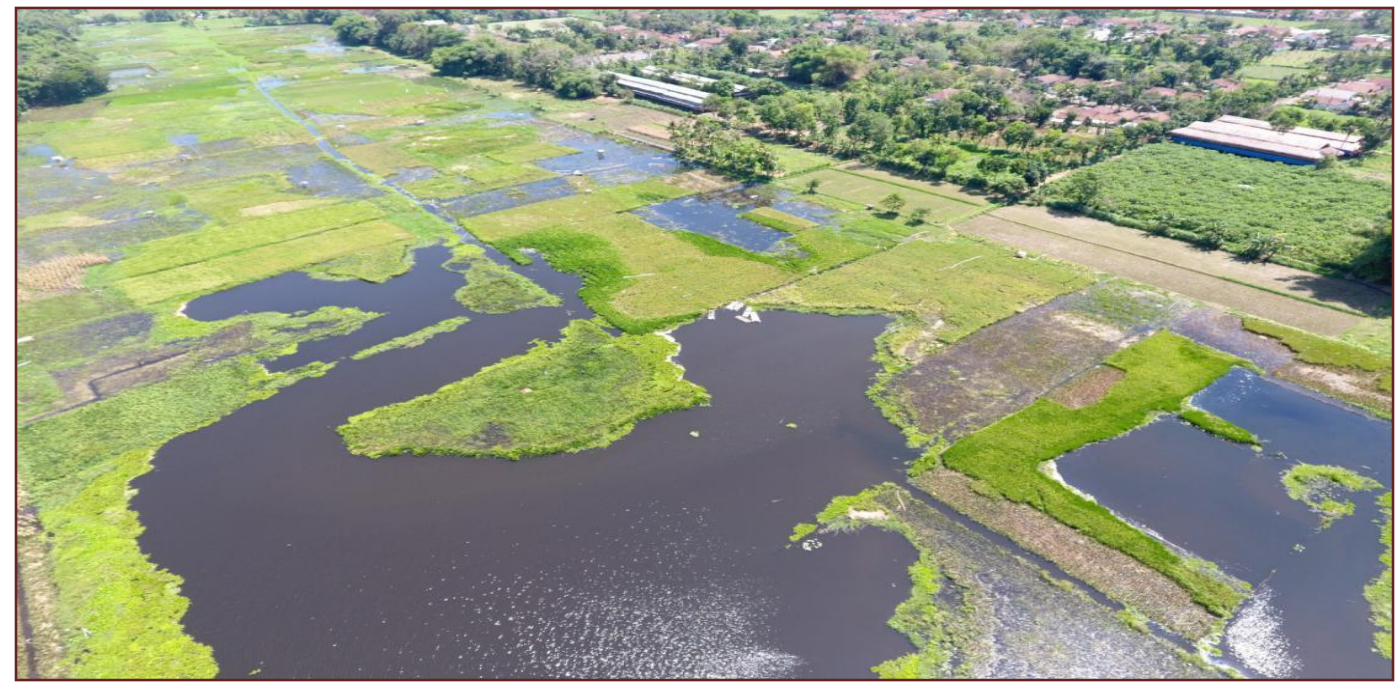

Gambar 3.1 Kondisi wilayah di Kecamatan Gumukmas diambil menggunakan Dji Pahntom 4

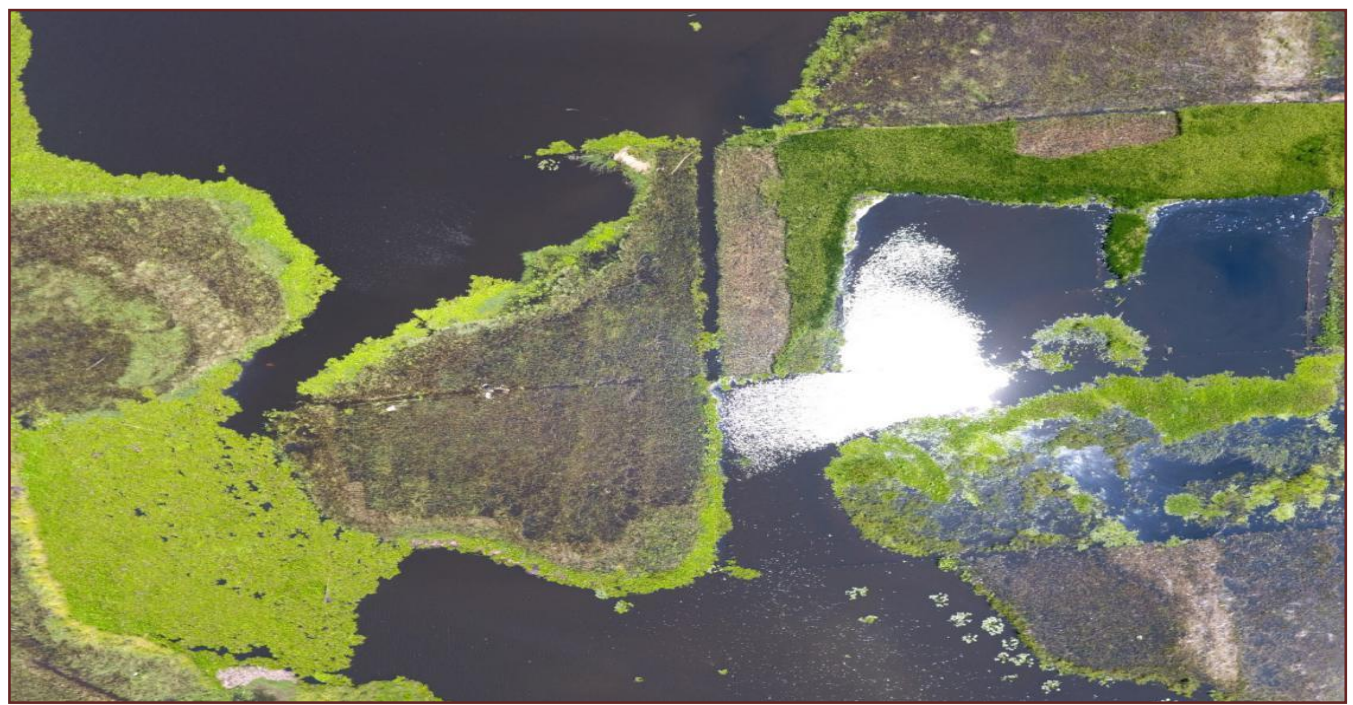

Gambar 3.2 Kondisi wilayah Gumukmas diambil menggunakan Dji Phantom 4

Dengan kondisi lingkungan yang seperti itu membuat masyarakat tidak berdaya, utamanya berkaitan dengan sektor pertanian, dengan keterbatasan pemanfaatan lahan, mengakibatkan banyak lahan yang sulit dimanfaatkan. Dalam Gambar di 3.1 menunjukan berapa luas lokasi lahan rawa yang tergenang, sehingga masyarakat tidak dapat memanfaatkan lahan yang luas tersebut untuk tanaman, langkah pertama yang tim lakukan adalah melakukan inventarisasi data luasan lahan rawa yang ada di wilayah gumukmas dengan bantuan mahasiswa dan masyarakat (partisipatif), sehingga kita dapat mendapatkan lahan rawa yang sebenanrnya di lokasi pengabdian. Kondisi lingkungan juga menjadi salah satu penyebab masyarakat desa terpaku dalam diam sehingga semakin sulit untuk 
membuka wawasan baru dalam mengelola lingkungan sekitar terutama untuk meningkatkan perekonomian yang dapat membantu pengembangan desa.

Ketersediaan pasar juga menjadi salah satu kendala bagi warga desa dalam mengembangkan potensi yang ada dilingkungan. Pemanfaatan hasil rawa seperti encenggondok pernah dilakukan namun karena ketersediaan pasar yang tidak suistanbility (berkelanjutan) dan kemampuan mengolah sendiri yang kurang membuat pemanfaatan hasil rawa terputus dan terhenti. Pengembangan SDM melalui berbagai cara dapat menjadi salah satu cara vuntuk mengembangkan potensi desa secara menyeluruh dan tepat sasaran.

Pembinaan yang dilakukan melalui Karang Taruna yang berada di Desa Gumukmas, Kecamatan Gumukmas Kabupaten Jember dilakukan oleh Tim pengabdian masyarakat universitas jember. Pembinaan tersebut di jabarkan dalam kerangka kerja yang sudah dibuat oleh Tim Pengabdian masyarakat dalam bab tiga. Pelatihan ini diselenggarakan atas minat dan permintaan dari pengurus karang taruna, pengayaan wawasan sains tanah dan jiwa enterpreneurship menjadi penting untuk mengembangkan pola pikir positif generasi muda di desa sasaran. Kegiatan ini dilaksanakan oleh tim yang terdiri dari 1 (satu) Ketua Tim dan 2 (dua) Anggota Tim yang memiliki kepakaran berbeda-beda dan sangat berkaitan serta dibutuhkan oleh tim untuk menyelesaikan persoalan yang akan dikerjakan di wilayah pengabdian. Harapannya kegiatan ini dapat tuntas dan berkelanjutan dari sisi kegiatan, sehingga kegiatan ini mampu menjawab tantangan yang ada didalam masyarakat, utamanya dalam pengembangan des wisata dan wirausaha sejahtera.

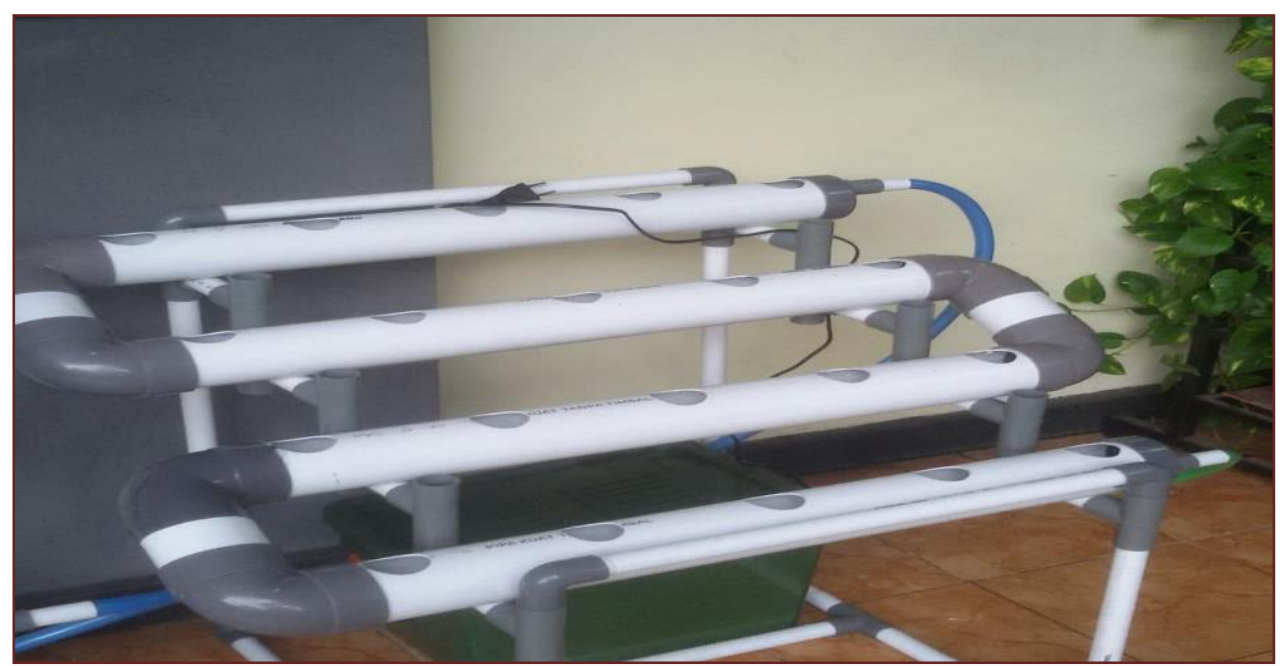

Gambar. 3.3 DFT (Hidroponik Deep Flow Technique)

Hasil dari kegiatan ini yaitu masyarakat dapat membuat instalasi hidroponik yang dapat di terapkan di wialayah masyarakat sendiri dengan 
subtitusi bahan alat instalasi yang akses nya mudah di jangkau dan ekonomis atau menggunakan bahan tidak terpakai.

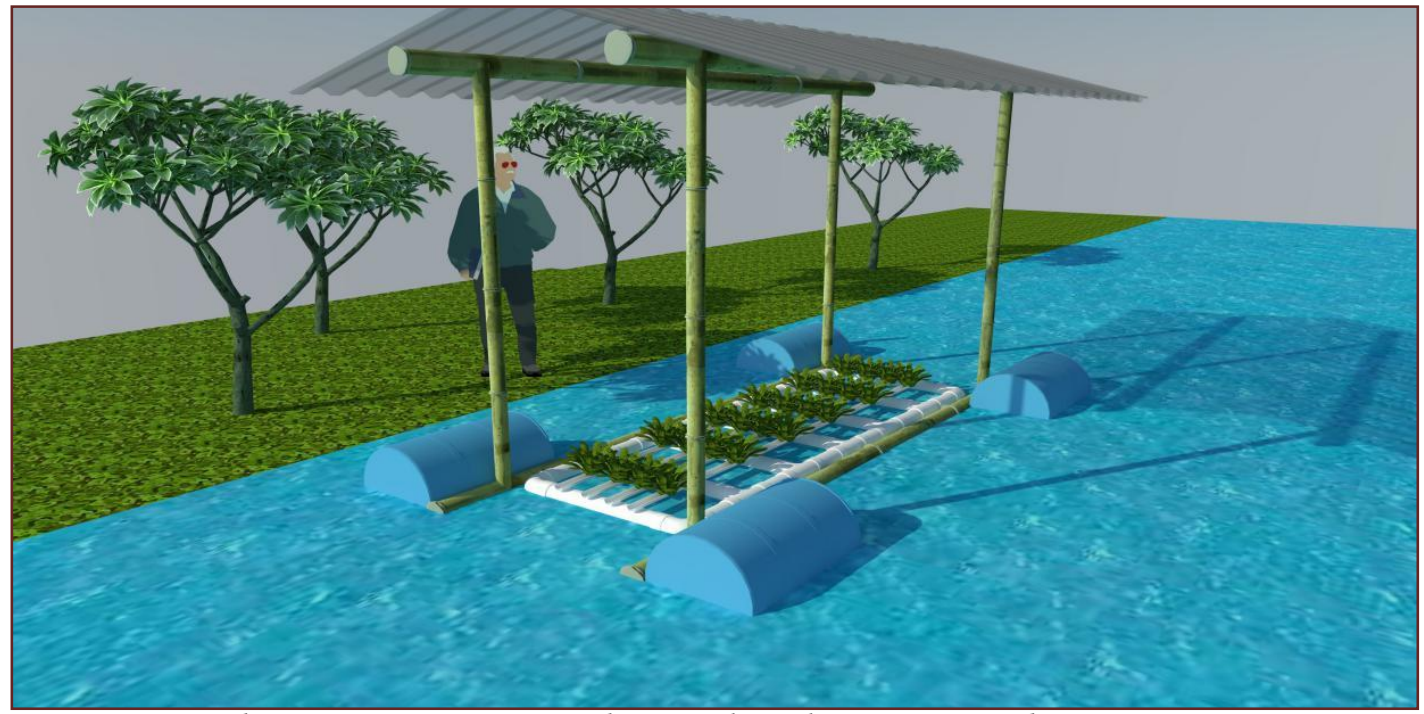

Gambar 3.4. Prototype Hidroponik Rakit Apung Lahan Rawa

Pembuatan rakit apung sederhana yang akan di pasang di wilayah lahan rawa ini mengadopsi sistem rakit apung sederhana dimana sistem ini sangat sederahana hanya saja sistem rakit apung lahan rawa, akan dilakukan di lahan yang alami. Hal ini di lakukan karena selama ini masyarakat sangat terbatas memanfaatkan lahan rawa hanya pada saat kondisi surut, sehingga lahan rawa dalam kondisi tergenang akan sangat sulit dimanfaatkan. Setelah dilakukan sosialisasi

\section{PEMBAHASAN}

Lahan pekarangan memiliki potensi dalam penyediaan bahan pangan bagi keluarga,sehingga secara tidak langsung dapat menghemat pengeluaran rumah tangga dalam rangka memenuhi kebutuhan rumah tangga. Hasil panen yang melimpah dari pekarangan rumah bisa manjadi salah satu potensi dalam mencari penghasilan tambahan dari produksi bahan pangan terutama sayur-sayuran yang higenis dan sehat bagi keluarga. Manurut Hidayati dkk,(2018) vertikultur merupakan teknik budidaya yang tdaik memerlukan lahan luas, dapat menggunakan lahan pekrangan rumah sehingga memungkinkan kita malkukan kegiatan berkebun secara efisien. Pengembangan pertanian dapat dilakukan cara ini sehingga masyarakat bisa lebih mudah dalam memproduksi bahan pangan hortikultura selainj itun dapat membantu kegiatan perekonomian secara tidak langsung selain untuk memenuhi kebutuhan sendiri. Program pengabdian masyarakat dengan pelatihan vertikultur merupakan solusi terbaik dalam rangka 
pengembangan desa karena cara ini mudah dan hasilnya dapat bersaing dengan sektor ekonomi yang lain. Vertikultur diharapkan menjadi salah satu teknik bercocok tanam yang dapat digunakan dengan baik oleh warga desa sehingga pekarangan rumah dapat dimanfaatkan secara maksimal dan dapat menjadi pelopor penghasil sayur-sayuran sehat untuk keluarga.

Kondisi SDM yang rendah di Desa Gumukmas dapat diatasi dengan cara pengadaan pelatihan serta sosialisasi secara berkala seperti proses pendampingan dalam penerapan teknik vertikultur ini sehingga hasil yang diharapkan. Pendampingan secara berkala mulai dari tahap pembibitan sampai pada tahap pasca panen sangat dibutuhkan dalam proses transfer pengetahuan tentang teknik pertanian secara vertikultur ini. Tahapan MOM adalah satu cara dalam melakukan pandampingan dengan masyarakat desa. Tahap MOM ( Manajemen Organisasi Masyarakat ) dilakukan dengan cara :

\section{A. Musyawarah Masyarakat}

Dipandu oleh Tim program pemberdayaan (Mahasiswa dan Dosen) untuk membicarakan setiap kegiatan yang akan diadakan untuk tahapan berikutnya. Melalui proses musyawarah yang dilakukan untuk mencapai kesepahaman antara pihak masyarakat dan Tim Pelaksana. Kegiatan yang akan berlangsung merupakan kesepakatan bersama dengan masyarakat sehingga pelaksanaannya diikuti dengan tanpa paksaan karena juga merupakan kebuthan pribadi. Keberlanjutan program juga lebih terjamin dengan adanya kepercayaan dari masyarakat kepada Tim Peneliti.

\section{B. Pembentukan TIM Pengelola}

Pembuatan vertikultur dari dari pihak masyarakat dan peneliti. Hal ini dilakukan untuk memudahkan koordinasi dan monitoring pelaksanaan serta pasca pelaksanaan dari kedua belah pihak agar kegiatan ini bersifat berkelanjutan hingga mampu bernilai komersil.

\section{Pelatihan Manajemen Organisasi Masyarakat (MOM)}

Adapun pelatihan yang akan diberikan meliputi memberikan penjelasan struktur Tim Pengelola yang tertata dengan benar, penyusunan tata tertib pelaksanaan program guna meningkatkan kedisiplinan masyarakat, mekanisme pengambilan keputusan bersama guna transparansi program, bagaimana cara menjalankan proses organisasi dalam Tim Pengelola dengan benar, bagaimana menjadi Pimpinan Tim Pengelola yang berkualitas dan mampu menjalankan organisasinya dengan efektifn, dan pembentukan struktur organisasi dari kedua belah pihak.

Pelaksanaan kegiatan ini dapat dilakukan secara bersamaan dengan masyarakat dan dilakukan monitoring secara berkala dengan melihat 
perkembangan program yang telah dilaksanakan, mengetrahui kendala dalam setiap pelaksanaan serta mencari solusi atas masalah dan kendala yang dihadapi dalam proses pendampingan. Cara ini dapat efektif sehingga pelaksanaan dapat berjalan sinergis dan berkelanjutan.

\section{KESIMPULAN}

Pelaksanaan pengabdian masyarakat Desa Gumukmas adalah satu cara untuk mengembangkan potensi desa secara mandiri dan berkelanjutan. Pengembangan potensi dengan pemanfaatn lahan pekarangan dan kahan rawa pada daerah sekitar rumah dapat menajdi tambahan panghasilan dan membantu warga secara ekonomi. Proses pelatihan dan pendampingan yang dilakukan secara intesif juga dapat menjadi sarana bagi masyarakat desa dalam memahami dan mempraktekkan teknik budidaya vertikultur. Dalam setiap pelaksanaan pasti ada kendala dan masalah yang dihadapi oleh masyarakat namun masalah-masalah seperti ini dapat diatasi dengan solusi yang murah dan mudah di dapat oleh masyarakat sekitar. Program pengabdian ini dapat berhasil dengan pasrtisipasi aktif baik dari peneliti, perangkat desa dan masyarakat desa secara baik dan intensif.

\section{UCAPAN TERIMA KASIH}

Kepala Desa Gumukmas

Ketua Kelompok Tani Rowopulo

Warga Desa Mayangan Gumukmas

\section{DAFTAR PUSTAKA}

Cahyono, B. 2014. Teknik Budidaya Daya dan Analisis Usaha Tani Selada. CV. Aneka Ilmu. Semarang. 114 hal.

Hidayati,N.,Piueyani.R.,Fahrudin.A,dan Nanang.H. 2018. Pemanfaatan Lahan Sempit Untuk Budidaya Sayuran Dengan Sistem Vertikultur. Jurnal Umpalangkaraya. 3(1):40-46.

Krisnawati, D. 2014. Pengaruh Aerasi Terhadap Pertumbuhan Dan Tanaman Baby Kalian (Brasicca Oleraceae Var. Achepala) Pada Teknologi Hidroponik Sistem Terapung Di Dalam Dan Di Luar Greenhouse. Skripsi. Jurusan Teknik Pertanian. Fakultas Pertanian. Universitas Lampung.

Lingga, P. 2005. HIDROPONIK Bercocok Tanam Tanpa Tanah. Penebar Swadaya. Jakarata. 80 hal.

Mas'ud, H. 2009. Sistem Hidroponik dengan Nutrisi dan Media Tanam Berbeda 
Terhadap Pertumbuhan dan Hasil Selada. Media Litbang Sulteng. 2 (2) : $131-136$.

Mechram, S. 2007. Aplikasi Teknik Irigasi Tetes Dan Komposisi Media Tanam Pada Selada (Lactuca Sativa). Jurnal Teknologi Pertanian. 7 (1) 27-36

Moekasan, T. K dan L. Prabaningrum. 201l. Program Komputer Meramu Pupuk Hidroponik Ab Mix Untuk Tanaman Paprika. Pusat Penelitian Dan Pengembangan Hortikultura. Jakarta. 20 hal.

Nazaruddin. 2000. Budidaya dan Pengaturan Panen Sayuran Dataran Rendah. PT Penebar Swadaya. Jakarta. 142 hal.

Primantoro, H dan Y. H. Indriani. 1999. Hidroponik Semusim Untuk Bisnis Dan Hobi.

Penebar Swadaya. Jakarta. 122 hal. 55

Riskiyah, J. 2014. Uji Volume Air Pada Berbagai Varietas Tanaman Tomat (Lycopersicum Esculentum Mill). Agroteknologi Studies Program. Faculty of Agriculture, University of Riau

Rohmah, N. 2009. Respon Tiga Kultivar Selada (Lactuca Sativa L.) Pada Tingkat Kerapatan Tanaman Yang Berbeda. Skripsi. Universitas Brawijaya Fakultas Pertanian. Jurusan Budidaya Pertanian. Malang.

Rosliani, R dan N. Sumarni. 2005. Budidaya Tanaman Sayuran Dengan Sistem Hidroponik. Balai Penelitian Tanaman Sayuran. Bandung. 27 hal.

Samadi, B. 2013. Budidaya Intensif Kailan Secara Organik dan Anorganik. Pustaka Mina. Jakarta. 67 